Chapman University

Chapman University Digital Commons

Pharmacy Faculty Articles and Research

School of Pharmacy

2016

\title{
Punk Philosophy as a Path to the Summits of Ethos
}

Vuk Uskoković

Chapman University, uskokovi@chapman.edu

Follow this and additional works at: http://digitalcommons.chapman.edu/pharmacy_articles

Part of the Other Philosophy Commons, and the Philosophy of Mind Commons

\section{Recommended Citation}

Uskoković, Vuk. "Punk Philosophy as a Path to the Summits of Ethos." Cultura 13.1 (2016): 29-47.

doi: $10.5840 /$ cultura20161312

This Article is brought to you for free and open access by the School of Pharmacy at Chapman University Digital Commons. It has been accepted for inclusion in Pharmacy Faculty Articles and Research by an authorized administrator of Chapman University Digital Commons. For more information,

please contact laughtin@chapman.edu. 


\section{Punk Philosophy as a Path to the Summits of Ethos}

\section{Comments}

This is a pre-copy-editing, author-produced PDF of an article accepted for publication in Cultura, volume 13, issue 1 , in 2016 following peer review. The definitive publisher-authenticated version is available online at DOI: $10.5840 /$ cultura20161312.

\section{Copyright}

Peter Lang Academic Publishing Group 


\title{
Punk Philosophy as a Path to the Summits of Ethos
}

\author{
Vuk Uskoković \\ Advanced Materials and Bionanotechnology Laboratory, Department of Bioengineering, \\ University of Illinois, Chicago, IL, USA
}

\begin{abstract}
Elaborated in this discourse is the idea that identifying with a punk persona is a necessary step in the ethical development of an individual. Offered are various ethical corollaries of standing on the punk philosophic grounds, including: (i) abomination of the art of following, (ii) appreciation of creative aspirations more than the technique, (iii) the necessity for the constant shift of the epistemic grounds on which one stands, (iv) revival of the aesthetics of Speer's theory of ruin values, (v) revitalization of language via its destruction, and (vi) embracement of anarchic revulsion of the concept of authority as a pathway to excellent educational efforts. It is also mentioned that science is inherently a systematic rebellion against stale, prejudiced thinking, and that, as such, it is intrinsically the endeavor of intellectual punks. The final summersault in the course of the philosophical gymnastics class of the hour pertains to realization that the anarchistic ideals underlying the punk culture foster ultimate freedoms that make even the abolition of these very same freedoms and obedience to any rules or principles legitimate. The failure of all the ideologies of the $20^{\text {th }}$ century has been in favor of the antiideology of authentic anarchism, and yet this ideology not only insists on ruining the relevance of any ideologies out there, but also calls for the deconstruction of itself, wherefrom the freedom to follow any ideologies under its umbrella naturally emanates.
\end{abstract}

Keywords: Aesthetics, Epistemology, Ethics, Language, Science, Punk.

\section{Introduction}

"The law entered, that the offence might abound; but where sin abounded, grace did much more abound”

Romans 5:21

"Quietly, something enormous has happened in the reality of Western man: a destruction of all authority, a radical disillusionment in an overconfident reason, and a dissolution of bonds have made anything, absolutely anything, seem possible. Work with the old words can appear as a mere veil which hid the preparing powers of chaos from our anxious eyes. This work seemed to have no other power than that of a long continued deception. The passionate revivifying of these words and doctrines, though done with good intentions, appears as without real effect, an impotent call to hold fast. Philosophizing to be authentic must grow out of our new reality, and there take its stand" ${ }^{\prime \prime}$

Karl Jaspers, Reason and Existenz, 1935.

It is said that whoever has never seen oneself as a punk at least during one period of one's lifetime will never grow into a decent persona from the transcendentally ethical standpoint. I cordially agree. Punk could be defined as a philosophy of disagreement, derail, constructive divergence and ruthless rebellion against habitually or timidly accepted social norms. 
Being at fundamental odds with the social structures imposed on us is a prerequisite for seeing its flaws acutely. This realization of flaws inevitably inherent in the substratum of reality is, on the other hand, a prerequisite for our contribution to its evolution into more sublime and organized states. So long as we are unequivocally exalted by our perceptions, without finding any grains of obsoleteness in them, we would never transform into a social escapee from which enchanting expressions emanate like the world has never seen. For, the other side of the coin of contention is resignation and immoral ignorance of ailments that have stricken humanity. Hence the essential importance of remaining squatted like a punk saddened by the state of the world at the center of one's consciousness. It is with this thought in mind that we set off to a short journey in search of a punk path to a stellar ethos.

\section{Origins in music}

Like many powerful social movements of the present and past, punk sprang from an artistic expression, predominantly musical. To be more precise, it was co-created in a thersitical marriage with it. Good music, in general, is born from sensible coalescence of opposites and punk music was no exception to this rule. In Jam's Going Underground, for instance, one could distantly hear armies of joy solemnly marching driven by dedication to live in accord with the ideals of some sublime beauty, but they do so side by side with legionnaires of anger over the oleaginous hypocrisies of the world. Sympathy and resentment, a couple of emotions hardly meshing in a harmonious medley and yet so typical for a UK punk song.

Consequently, a great majority of punk songs reverberate with a strident political message and synchronously stir a sense of heroism in the listener. If it were not for the notorious lack of interest in developing musically among their protagonists, the pantheon of the British and Yugoslav punk would have been embellished by far more ornamental pieces than it is. Still, their ephemeral luster derives from their being distillable into (i) the essence of the vibe of the Internationale with its calling for empathic embracement of all classes, and (ii) an aural incentive in the direction of self-independence rather than of shadowing the trends and ideals served on our plates by the governing authorities. The sound of empathy coupled to the sound of breaking barriers and setting fences on fire, as if a Berlin Wall falls with every fine punk piece, is thus immanent in the tunes from this musical genre. It is, though, usually blended with the inward pull whereby conformist threads woven between the mind and its social milieu are torn, yielding a crucifying confluence of opposites, in the spirit of masterful musical compositions in general. The American indie music, having outgrown from the musical branches that faultily place themselves in the punk pocket, emphasizes the latter, self-reliant and self-sufficient aspect of the British and Yugoslav punk, while neglecting the spirit of heroic partisanship in it. The resulting are one-dimensional sound waves that drown the listener in the waters of emotional lameness and self-indulgence.

Although in 1979 it may have seemed as if the British, the Yugoslav and the North American punk scenes - with the latter evolving from the seed of the CBGB scene and then turning increasingly hardcore along its westward route - all belonged to a single musical stream of fashion, from today's perspective it is clear that the main holders of the punk flag in the US were not punk bands at all: Ramones were a parody on the rockabilly style, the New York Dolls were merely an extravagant rock band, Blondie was an attempt to create yet another airheaded and bubbly Barbie-dolled pop star, Dead Kennedys were a satirical Oi! spinoff, Television were a prog rock ensemble, while Patti Smith was a punk as much as Beethoven was a classicist; 
although she may have begun her career in something that resembled punk clothes, with her first record, Horses, she swiftly distanced herself from it, setting grounds for markedly more complex and sublime levels of pop artistic expression compared to other members of the New York City punk scene. The world had to wait for a whole decade until an authentic gem reflecting sparkles of untold signs of the times of the New York City punk scene was fashioned: Sonic Youth's Sister. Older and truer influences of the tediously dismal vibe of the indie scene in the US number the Velvet Underground and, unavoidably, the Beach Boys' Pet Sounds, revealing the dark sides of this timeless record. In fact, many Pitchfork Media favorites, self-pitiful antiheroes at their best, largely built on the musical premises (and promises) of Pet Sounds, exemplify what typically happens to extraordinarily original and influential human deeds when they are turned into adoration objects worth insane following: their genial, sympathetic, "pet” side becomes paler and paler, while its dark, sulky, "pat" side becomes amplified, letting the spoiled spirit of idolatry ravage the essence of these exceptional works with the passage of time.

\section{Punk as a stop sign to the sin of followers}

The sin of followers can be blamed for the recurring historical tendency for human ideologies to wander off into their diametrical opposites as they become implemented in the society, with communism, Christianity, Darwinism, Pythagoreanism, empiricism and, some may even say, capitalism, switching things from the ideologically negative to existentially positive to some extent, being the notable examples. Christianity, for one, has undergone transformations to its diametrical opposites during its past and present, from the original teaching of repentance, of incessant questioning oneself and abstaining from judgments, never ceasing to forgive and, simply, love it all to teachings that emphasized crusading, conquering and piercing with swords of judgment and disgrace all that appears peculiar and uncommon to the bigoted eyes that stand behind them. Totalitarian communist regimes that distorted the anarchistic ideals of abstaining from governing anything or anyone are another example of how easily and unnoticeably the human mind applying a specific teaching can slide onto a track that takes it in a direction fundamentally divergent from the destinations originally envisioned. This reversal of the core of great ideas into their wrong and often literal interpretations, producing tragic consequences along the way, is ascribable to the sin of following.

Punk philosophy, on the other hand, is all about the ruthless abomination of the art of following. An anecdote tells of a perplexed boy walking up to a girl in a quiet moonlit alley and asking her, "What's punk?” The girl silently kicks over a garbage can. The boy then kicks over the garbage can himself and says: "So, that's punk?" "No, that's trendy", the girl says. Or, the crossed writing on a crumbly brick wall, spread anarchy, and a new one sprayed next to it, don't tell me what to do!! ${ }^{2}$, a logical response to a message underlain by misinterpretation of the ideal of anarchism as a rebellion against any form of authoritative control of another's thoughts or actions and rigid indoctrination by an ideology that was supposed to liberate one from it.

In Bruce Norris' Clybourne Park, a Pinteresque play filled with mundane conversations through which actors incessantly switch roles and thus let pretence crumble away and interpersonal tensions dissipate, a joke is told: "How many men does it take to change a real light bulb? All of them: one to hold the bulb and the rest to screw the world" ${ }^{3}$. Concealed in this joke as its tragicomic punch line is a viewpoint that depicts the sin of followers in life as inescapable. In fact, the Biblical story of the expulsion from Paradise insinuates that the primordial sin of followers may be deeply encoded within the core of our beings. For, when the Lord asked why 
the forbidden fruit from the tree of knowledge was tasted, a chain of blaming one another ensued (Genesis 3:9-13), and the choice to follow in life is always paralleled by a similar shift of responsibility onto others for the decisions one has made. Yet, only when the impulses for our actions begin to be derived from the center of our consciousness, a gulf between ourselves and the surrounding creatures will be built as a ring of remoteness across which the sunrays of a shiny spirit will be able to gain speed, coherence and dazzlingly enter the eyes of the world. The building of this gulf that separates us from the social reality so as to bring us ever closer to it is the essence of the punk ethos.

What lies concealed in this viewpoint is a seed of the anti-doctrine called anarchism. Although many equate anarchism with disarray and chaos, its true meaning pertains to the idea that unquestionable submission to authorities, as well as power over another, coincides with extinguishment of the creative powers dormant in us. Or, as the verses jotted down by the $19^{\text {th }}$ Century Serbian children's poet nicknamed the Dragon, that is, Zmaj, have it, "A pocketful of words creates future: I have no master, they spell". When asked whether anarchy is when "the riots, violence, looting, and destruction spring up in place of a crumbling government”, Alan Moore's V responds saying, "No. Anarchy means 'Without Leaders'; not 'Without Order",4, that is, "the absence of a master, of a sovereign", the way Pierre-Joseph Proudhon put it in $1840^{5}$. Or, as the message which Aesop placed as the exit line in one of his fables ${ }^{6}$ and which Paracelsus later adopted as his medical motto tells us, alterius non sit qui suus esse potest, that is, "let no man be another's who can be his own”. This is a logical response to realization that any ideology that becomes dogmatic and autocratically propagated, irrespective of its ethical propensities, turns into disaster. In a nutshell, the ultimate message of the philosophy of anarchism is that a sense of authority hanging over our heads is equivalent to our subjugation to carrot-and-stick conditioning and, as the teaching of Bhagavad-Gita points out on innumerable occasions, whenever we conceive and conduct our actions with the purpose of reaping rewards for the benefit of our ego, we corrupt the spiritual content of their fruits.

\section{Hail to the aspiration, not the technique}

Every critic of the modern music knows that minimalism and straightforwardness of punk sound singlehandedly killed the intricacy and suffocating solos of progressive rock and occasionally made even the best of classical composers of pretentiously structured and cerebral pieces blush, as much as simple fountains of Rome hidden along cobblestoned sideway alleys, such as the mask fountain in the park of the Orange Trees, or behind dense bushes of the local forest, as in the case of the fountain of Moses in the Pincian Gardens or the one in the gardens of Villa Sciarra ${ }^{7}$, have often made many of the pompous watery monuments of the Eternal City blush with their modest, unassuming and yet inexhaustible aesthetic appeal. Likewise, some of the classic equations that propelled science and technologies in whole new directions were extraordinarily simple, from Newton's equations that set the bases of classical physics to Einstein's mass-energy equivalence and the equation that expresses the photoelectric effect to Heisenberg's uncertainty principle to Planck's definition of the quantum nature of light to de Broglie's equation that describes particle-wave duality.

From this ability to enrich the mind with the most minimalistic of means another essential message of punk springs: not what we do, but in light of what aspirations we do what we do is what truly matters in life. Another way of phrasing this ultimate message of punk rock is that even when you do not possess the most brilliant playing technique, if your heart burns with 
wishes to save the world, your art will glow with it and unstoppably live up to this ideal, subtly and imperceptibly at times, but still flawlessly and unfailingly in the eye of the whole.

Romanticism in music arose from the attempts to combat classical virtuosos who saw delicate technique as the greatest summit of creative expression with simpler but more aesthetically touching pieces of art, and the same line of progress whereon vulgarity of those who embrace sheer technical mastery, overconfidently and with cold hearts, is subdued to those with little resources but with warmly beating hearts big enough to fit the entire Universe within can be said to be epitomic of the story of humanity as a whole. As we move from the level of a novice, where a lack of playing technique can be made up for by great passion to produce novel and enlightening expressions, towards the level of an experienced artist, the lack of passion often tends to be substituted with merely an excellence in technique, resulting in petty works and explaining the phenomenon of the best and unsurpassed first record of countless punk bands. In that sense, the words of Jean Lescure offered in his study of a painting by Charles Lapicque could be recalled: "Knowing must be accompanied by an equal capacity to forget knowing. Nonknowing is not a form of ignorance but a difficult transcendence of knowledge. This is the price that must be paid for an oeuvre to be, at all times, a sort of pure beginning, which makes its creation an exercise in freedom" 8 .

"In the poem about love you don't write the word love", was the title of an exhibition of the painter Sue Tompkins, one of the most astonishing punk singers of the new century, who has known that beauty we throw into the face of the world depends not on the meanings of the words we say, but on the manner in which we tell them, on the sea of intentions upon which the ships of our words float. A punk voice that overwhelms one with the feel of beauty, braveness and awe in spite of its acoustic thorniness ${ }^{9}$, compared by the critics to "the scrape of fingernails on a blackboard" 10 , evoking the climbs to the peak of the pyramid of human knowledge whereby not the surface, but the essence becomes fallen in love with, is what one such approach to creative expression has yielded. So, when Calvin asks, "Do you think our morality is defined by our actions or by what's in our hearts" 11 , the answer is crystal clear.

This flies us back to Tao-Te-Xing, the beginning of it all, and the moment in which LaoTzu claims that "teaching without words is the highest peak of teaching" (II). For, to reiterate, what matters most is not what we do or say, but how we do or say it, that is, with what level of enlightening drive we spin the wheels of our movements in space to express ourselves. What the punk philosophy, stretching its arms throughout the history from Lao-Tzu to Socrates to the Christ to Heinz von Foerster to other thinkers, has taught is the art of acting with the foundations of our being washed with the waters of sublime ethics, while leisurely playing on the surface with quite often contrasting impressions. All of us who raise essence over form and spirit over surface may thus agree that a preacher with a lukewarm heart who "honoreth God with his lips only" (Mark 7:6) will never come close to "a hooker with a heart of gold"12, firmly believing that not lines drawn in the sand, but emotions, intentions and aspirations that stand in the backdrop of our endeavors are what truly matters and determines the profound, long-term success of our ventures. Many punk rock musicians have consequently resorted to insertion of ironic statements that opposed their real beliefs in the lyrics and titles of their songs, let alone words spoken during interviews, having realized the liberating effect this has on their spirit by dissolving the stiff shell of their ego. For, opinionated self concerned about the light in which others will see him is an egotistic self too and by finding freedom to proclaim anything, irrespective of how contradictory assertions made now are from those made seconds ago, the egotistic crust fencing a blissful spirit is being removed and this inner light could be released outwardly. Malcolm McLaren, who 
originated the concept of Sex Pistols as sprouts of the British punk rock movement, thus reflected on one occasion on him "deciding how to use 'bad' and make it work in a way that ultimately might change popular culture itself" 13 , probably unaware that he had touched the roots of a more profound philosophy which practically no one in the trendy movement he had initiated knew anything about. This is the same philosophy as the one that has taught for millennia that a true ingenuity lies not in discarding the ugly and embracing the pretty, but looking for the patterns of beauty in both.

\section{Punk and the ethics of self-annihilation}

It has been customary for punk musicians to smash their instruments at the ends of their performances. Were they being aware of the metalogical significance of this act I know not, but what I see today as the message intrinsic to this act is the ethical necessity to use our tools to destroy these very tools when the work is done and point at the transcendental vistas that lie further ahead. This act that evokes the destiny of a seed that has no other choice but to die before endowing the world with its spirit (John 12:24-25) and that ought to finalize the very act of creation I find as a key idea behind the punk philosophy. The same principle that calls for constant ruination and restoration of foundations applies to our epistemologies too. That is, in spite of the fact that perfect wonder is utopian, as questions can exist only on the basis of prejudicially accepted tautologies, unceasing sacrifice of the most intimate epistemic bases of our worldviews is needed to prevent us from slipping into the chasms of blind dogmatism.

To sacrifice what one values most and remove the grounds on which one stands is the ethical necessity from the punk perspective. When Sex Pistols shoved away the concept of being a fan that naively consumes what is being pipelined to him by the musical industry, with Johnny Rotten yelling, "Blind acceptance is a sign of stupid fools who stand in line"14 to buy their record, they engaged in one such ethically sublime act of self-destruction. And just like Sex Pistols implicitly disparaged the band's own signing a deal with the corporate moneymaking machine of a big record company in this final song of their debut album, Joe Strummer announced the record company's “complete control, even over this song” 15 in a song released by the very same record company as a part of his own debut as a member of the Clash, cutting off the branch on which he was sitting thereby in a self-destructive act that constitutes a prerequisite for exhibitions of true ethicality. Beethoven was also a punk when he called his fans cattle and asses for demanding encores of other movements of his String Quartet No. 13 during its premiere, and not the then futuristic final part now known as the Grand Fugue, and so was John Lennon when he sang to his supporters filling every last spot in the Albert Hall that famous "now they know how many holes it takes to fill the Albert Hall”" ${ }^{16}$. Both of them shoved their sheepish followers for their own good - to foster their independence and autonomy. Of course, to shove one's own supporters in such a strikingly direct manner requires one to step out of the selfcentered limits of one's own ego and think in a genuinely selfless, altruistic manner. For John Lennon, apparently, it was losing his fans and supporters and turning them into equal sources of creativity as he was that he equalized with the true triumph rather than making them addicted to the products of his own work and talents.

The final live appearance of the Sex Pistols, at the Winterland Ballroom in San Francisco on January 14, 1978, was denounced by the critics as “the worst rock ' $n$ ' roll show ever... a zombie performance, people who were already dead, reanimated for a while, going through their motions”17. Decades later, however, a punk chronologist, Nicholas Rombes saw in this final act 
of the founders of the punk movement a sprout of loyalty of the band to their ethos of anarchistic destruction of any methods, rules or principles and noticed that once the shocking outbursts of the spirit of revolt that the punk movement based itself on became popular and lost its edge, an authentic punk band had no other choice but to annihilate itself: "The final Sex Pistols concert effectively put an end to the notoriety of punk's method of provocation... In confirming the public's expectation, the Sex Pistols also destroyed them. They were against method. Which meant they had no choice but to destroy themselves" ${ }^{18}$. One of the central axioms of the punk movement can be directly derived at this point: namely, not only does the failure in the eyes of critics usually entail all the utterly progressive acts, but, conversely, deliberately making our performances a failure can also set the grounds for a long-term success.

Hanging onto these cords that tie ethical excellence and self-annihilation together, I am being flown to the heart of a medical enterprise, like the one that nests my professional identity. Therein I wonder how many medical professionals would give away their jobs if a magic fairy offered to eradicate each and every illness on the face of the planet. To what extent are they crows that stand out in the field and territorially repel those that shoot equally high on the academic ladder? Could it be the subconscious tendency of people to secretly wish for the fault in reality, social or physical, that they have noticed and pointed at in their ideas to remain uncorrected just so that they could be praised for these findings, irrespective of how damaging for the world this fault may be? "What would you be doing without sin", Charlie Chaplin asks a priest in Monsieur Verdoux, pinpointing the necessity of the existence of problems that one is busy solving for one's problem-solving profession to keep on thriving, being the state of affairs that offers as much room for exhibitions of hypocrisy as the sky is wide. Many are thus moralists that preach about obligations to be virtuous and stay away from various vices, and feel perfectly content doing this, while somehow failing to realize that their contentment is conditional on the vices that they fiercely criticize. The ethics of punk puts an end to this fundamental hypocrisy by an act of self-annihilation.

\section{Punk and the destruction of language}

What tool in need of annihilation do we, intellectuals, the readers of these lines, utilize more these days than language? None, I deem. This discourse thus implicitly revolves around the destruction of language as we have known it, the destruction that is necessary for the creation of more elegant and beautiful linguistic expression to begin to flourish.

For, what is the use of language, a punk in me says, if anything said is alright so long as somewhere deep inside of the speaker the sprouts of unspoiled goodness lie hidden? Will the words uttered lead to creation of benign deeds even when their superficial meanings oppose the benevolent intentions? I thus enjoy breaking the rules of clichéd communication through language to demonstrate that the reason why we are all here is because we should evolve beyond language and use it as a medium to exchange sparkles of the truer essence of our minds. Whether I may resort to statements such as Gertrude Stein's "a rose is a rose is a rose is a rose"19, a train of affirmations of identity whereby the meaning of this identity, along with the meaning of the word per se, is being dissipated in the wind, or an ever more profound assertion uttered by a Buddhist monk after he had picked a yellow rose from a vase, "a rose is not a rose; that is why it is a real rose" 20 , the ultimate mission of my verbalizations will be the same: to use words as a tool for their own sacrifice and annihilation, so that our minds could no longer be stopped by their barricades on the way to coalescing with and comprehending reality in a most direct fashion 
possible. In such a way, instead of stopping at the gate of language, we would pass through and emerge on the side of livelier and more interactive ways of being. For, it is only acting, singing, playing and dancing that can touch the depths of profound being. Everything else is merely grazing the outer edge of Pascal's circle that Nature is, the circle the center of which is everywhere and circumference nowhere.

\section{Punk as the aesthetics of ruins}

A world perfectly ordered naturally calls for a revitalizing blow of chaos through, lest its evolutionary propensities be brought to halt. For, as implied by the laws of thermodynamics, a system that does not hold even a wisp of entropy in it descends down the path of degradation and the opportunities for progress open only where symmetry and chaos coalesce. Thus the splendor of Albert Speer's theory of ruin values, according to which buildings, and most probably any other pieces of human creativity, should be made to degrade into aesthetically pleasing ruins, the concept which the German architect applied in planning for the 1936 Olympic Games in Berlin, having Parthenon and other ancient ruinous monuments as the ideal. This theory continued to thrive in the hearts of Berlin punks who lived up to the ideal of Einstürzende Neubauten ${ }^{1}$, the movement preoccupied with introducing flowery fragileness into post-World-War-II buildings endowed with a sense of sterile plasticity and perfection. And just like the cities would begin to breathe once again with the energy feng shui masters have mysteriously sensed to flow through harmoniously designed houses, domes, halls and whole cityscapes if their overly symmetrical and ordered, orthogonal and grid-like structures and superstructures were to be transformed into something more orderly disordered and tidily disheveled, so would the inspirational potential of our beings benefit from crushing our habits to pieces, habits that confine our endless potentials to amaze with innovative moves, moves that are capable of engraining mountains of emotiveness in them, to uninspiring behavioral narrowness. Eugenio Barba has thus considered the mental and physical state of Disorder wherein all the habits and behavioral clichés stand erased as the one that enables the actor to become "a bridge between the two extremes: the incursion into the machine of the body and an opening for the irruption of an energy that shatters the limits of the body" 21 . Concordantly, at the entrance to the Exploratorium, one of the seats of the muses of scientific wonder in the city of San Francisco, founded by Frank Oppenheimer, the wizard and a visionary to whom knowing how to break the rules was the starting point of creativity, inside of a rotating column, behind a magnifying glass, the words excerpted from a newspaper article by Herb Caen, the coiner of the term "beatnik", inviting us to realize that things could be indeed restored by ruining them, stand written: "As for the esthetic aspects of this berling controversy, I think the Rock should be allowed to go to rack and ruin. Every city should have a ruin" 22 , and as a Sanai's verse tells us, "Treasure abounds in ruins"23.

This theory of ruin values intrinsic to the punk attitude prompts us to look for intellectual stimuli in perceptions and sensual impressions that seem unpleasant and repugnant at first. For, only when we find indescribable joy in hugging the stinky, the raggedy and the old; only when the dusty and ruined visual landscapes fill us with diamonded insights; only when we understand that expressions appearing unappealing on the surface will be the sources of greatest satisfaction for our souls will we be able to claim the diadem of higher ethos as ours, the diadem that we could paradoxically hold on to for only as long as we tirelessly remove it from our head to

\footnotetext{
${ }^{1}$ Collapsing New Buildings would be the literal translation of this German phrase.
} 
decorate another's with. Punk values are thus about turning the popular pedestal of mainstream values upside down and prompting us to understand that what assumes an alluring and pretty surface is usually toxic for our spirits, while what appears gritty, grainy and dusty on the outside typically hides invaluably precious treasures within its core.

When Marcel Duchamp proclaimed his urinary to be a piece of art, a Fountain, he may have wanted to tell us implicitly not only that even the most vulgar and filthy objects can be considered works of art, but that peeing on something that is considered sublime and uplifting, such as an artistic piece in a museum is, is the right approach to more profoundly understand and appreciate the beauty of life and human creativeness that surrounds us. He did this in the spirit of conceptual art, which by definition serves the role of questioning the nature of art itself, turning into and against itself and in such a way finding a more enlightened ground for questioning the world around us. Sometimes I wonder whether installing this specific urinary in museums brought a sense of accomplishment in the artist, due to the fact that he managed to mingle one such ordinary and even disgusting object among the artistic pieces that strive towards the standard concepts of beauty and clarity, or it was yet another striking disappointment in the nature of human beings for the artist due to the fact that the message he wanted to convey, that is, peeing on elevated art forms and celebrating the beauty seen in ordinary objects that are everywhere around us, was misunderstood by treating that specific urinary as a precious museum artifact that attracts people from all over the world to see it. And speaking of peeing, "I don't use the toilet much to pee in. I almost always pee in the yard or the garden, because I like to pee on my estate” is what Iggy Pop, who had sung earlier about shedding lights onto things in life that lack beauty and are as such ignored and unappreciated by the world ${ }^{24}$, said to remind us of the authentically punk aesthetics of diminishing and humiliating oneself in face of the world, of lowering oneself before others and becoming a sea into which all the rivers flow.

\section{The merits of punk in the world of science}

The merits of punk philosophy in the world of science could be immense. For example, if I were allowed to reorganize the publishing domain, I would initiate building of a world online library where all works ever written could be found, and where each one of us would have an unlimited access for free. After all, the word publishing has the connotation of making something public, available to all, rather than only to a handful of privileged ones. This way of thinking places me and the muses of punk philosophy that charmingly wink at you from behind these statuesque letters along the line of endeavors of Edupunks who have fought to enable free access to all the university-based educational contents for all, thus potentiating education as a free choice rather than a privilege of those who can financially afford $\mathrm{it}^{25}$.

Secondly, anarchism, the idealistic heart and soul of the punk movement, stands at the root of the most ethical educational approaches. An ideal education should empower students with the power of independent thinking, something that could be achieved only insofar as they are being given a relevant role in decision-making processes rather than pressured to comply with commands handed out to them by the authoritative teachers. For, being commandingly micromanaged impels one to think with the head of an authority rather than with one's own head, which is why building one's leadership on micromanaging insistence to obey orders is a perfect way to breed passive dependence instead of inventive independence. In such a manner, the powers of independent thinking are not being spurred - the task whose fulfillment stands for an authentic purpose of the academic training - but heartlessly ruined. 
With the most excellent education being tied to the fosterage of independent thought instead of producing a cult of flaccid followers, it comes as natural that teachers ought to teach students how to break the rules which the very schooling of theirs insists on, including keeping them under the limits to which their own creative selves have reached and guarding the gate that leads to their penetration through and beyond these limits. Teaching that is aware that the most essential learning steps are created upon breaking the rules conveyed by the very teaching is thus the only genuine teaching, very punkish in its essence. In agreement with a train of thought of one of the founders of the ideology, or, I should better say, anti-ideology of anarcho-pacifism, Bartholomeus de Ligt, who concluded that "the consistent pacifist must be an anarchist just as the consistent anarchist must be a pacifist" 26 , we should be aware that there is joy being born in this world every time we, as a holder of an authoritative stance, reach downwardly, so as to share our authoritative powers with those who have been deprived of them, as well as when we, standing in subdued positions, in cul-de-sacs of hierarchical pyramids, show no interest to climb up and claim the voice of an authority, but rather find infinite satisfaction in enjoying its view from below, under the enchanting starry sky, with arms gently grazing not the peaks, but the foundations, the elements of earthly edifices that determine their true strength and stability.

Anarchic views inherent in the punk attitude are also the only adequate grounds for liberation from rules and precepts that suffocate creativity. Science, after all, is inherently an adventure of the mind and a systematic rebellion against stale, prejudiced thinking. With any dogmatically predetermined routes to inference being the enemy of science, the claim that science is intrinsically the endeavor of intellectual punks should not surprise anyone. For, every question that springs from the sense of wonder in us can be recognized as a rebellious sparkle in its going against the stream of paradigmatic thinking. Only because of its inherently defiant nature with respect to the way of thinking that tends to lock itself into preprogrammed and reproducible modes does this questioning attitude, which we are incessantly allured to substitute with the omniscient spirit that endows epistemic conformists and followers, hold a central place in the adventure of the human mind that we call science. Consequently, since a genuinely scientific, deeply wondrous mindset is inherently tied to intellectual and spiritual rebelliousness, it comes as no surprise that some of the most brilliant minds from the history of humanity have struggled with the authority during the schooling stages of their lives, which is also why one can proclaim that it is practically a duty for all of us to stand against the traditional, conditional forms of education.

Yet, a catch exists here. We have seen that the ultimate doctrine of the punk philosophy is that there is no doctrine to be followed. This, however, includes this ultimate doctrine. After all, stating with a perfect certainty that uncertain is the nature of anything beautiful and progressive in life or claiming that there are no doctrines and rules in life to be stuck to would be yet another, essentially quite hypocritical instance of indoctrination in light of an unnaturally opinionated certainty. Adopting one such ultimately anarchistic perspective from which no rules are left to be obeyed in the game of life, including this basic rule, which essentially enables us to follow any rule we would like to, also prevents us from indulging in ideological indoctrination of others with the doctrine that banishes all doctrines and from being akin to the militant anarchists who are blind to the fact that they mirror the ideological side that they fight against and try to impose their own "no-ideology" ideology on. An important exercise employed in acting schools as a part of the Stanislavski method involves students making summersaults on trampolines, for in such a way the power of decisiveness in them is boosted and the wheels of willfulness spun ${ }^{27}$; similarly, the philosophy of anarchism with its fosterage of ultimate freedoms that make even the abolition 
of these very same freedoms and obedience to any rules or principles legitimate can be seen from this angle as an exercise in logistical acrobatics, a summersault after which things appear essentially the same as before, while the subject, himself, is revitalized and ready to freely take on any of the countless options posed before him with greater enthusiasm. The failure of all ideologies of the $20^{\text {th }}$ century can be a sign in favor of the anti-ideology of authentic anarchism as the only ideology worth following, the ideology that does not only insist on ruining the relevance of any ideologies out there, but also calls for the deconstruction of itself, as selflessly as it could be, wherefrom the freedom to follow any other ideologies under its umbrella naturally emanates. For, just as the political philosophy of democracy, an offspring of the broader philosophy of relativism, which is to be blamed for the contagious passivity that plagues the modern youth and the intellectual elites, is undergoing a massive decline in popularity in many parts of Europe today, leaving an ideological vacuum in the wake of retreating traditionalists and democrats, so is embracement of freedoms and freedoms only bound to prove itself as toxic and unsustainable in the long run if it remains unbalanced with principles and laws, even if they be as changeable as weather on a May day in Chicago. A fantastic summersault in the course of this philosophical gymnastics class is thus being made, from confinement within ideological shackles to perfect freedom and back, confirming the well-known systemic fact that no freedom could exist except within the boundaries of precisely defined laws and constrictions, and vice versa: freedoms are to be exercised to sustain the stability of the existing rules and prescripts.

After all, without following these lines we would have never arrived at the understanding of one another. Our horizons of thought, if I am allowed to use Gadamer's metaphor, would have never overlapped. In that sense, without balancing the incentives to autonomously differ and communally follow, no truly creative being in this world could be given rise to. By grasping one such anarchistic freedom of choice, one is free to choose between general dissent and voluntary subdual of this freedom to "the fetter of a greater freedom", as Kahlil Gibran poetized ${ }^{28}$, that is to say, to actions arising from the feelings of care, love and devotion, which would anchor our beings to the earth, prevent them from being lifted into sterile and vacuous spaces that surrounded Major Tom floating in his capsule and make us instead land onto realms of palpable creativeness where these astral seeds of thought may finally find a fertile ground.

In other words, it is always the balance between compassionate following and rebellious differing that is worth striving for in life. The other side of the coin of the punches of awe and wonder delivered by the punk in us is LOVE.

\section{Conclusion}

We have walked the path with a hand-drawn sign on it, saying Punk, luscious and terrifying at the same time, and let a few gates along it ajar. Thus we have glimpsed little insights that highlight the connection of the punk compendium of values with remote naturalistic and humanistic disciplines. We recalled the musical origins of punk in the blink of an eye; we got reconnected with its anarchic epistemological grounds; we traversed its trail on the territory of science and education; we got reminded that if hearts are empty, what lies in the heads matters not; we began our climb to the summits of a stellar ethos that it windingly ascends to, and all that for the sake of marking insights for the future relevancy of this hypermodern überphilosophy. Yet, more is to be explored and what has been only touched now ought to be charted in far greater detail. 
In the end, every expression should walk its talk. That is to say, a complete structure makes its semantics obvious in each and every one of its aspects and elements. To preach punk while resorting to the language of snotty intellectualism and conventions of grammar, not being courageous enough to "get it all down and without modified restraints and all hung-up on like literary inhibitions and grammatical fears" ${ }^{29}$ therefore makes us snobs, not hearty punks. And in order not to be a hypocrite at the end of the road, I will let language, the implicit subject of this short discourse, shatter into a shimmery semblance of the starry sky, incomprehensible but dazzling and mysterious, a silhouetting chiaroscuro, an anahata sound, a squirrel and a pine needle, and then a star.

\section{References}

${ }^{1}$ K. Jaspers - "Reason and Existenz", Translated by William Earle, Johs. Storm Verlag, Bremen, Germany (1935), pp. 23.

2 J. C. Scott - “Two Cheers for Anarchism”, Princeton University Press, Princeton, NJ (2012).

${ }^{3}$ B. Norris - “Clybourne Park: Act II”, Faber and Faber, New York, NY (2011).

${ }^{4}$ Anon - “Girding for War: A Journal of Christian Anarchism \#0”, San Francisco, CA (2011).

${ }^{5}$ P.-J. Proudhon - “What is Property?”, Create Space, Scotts Valley, CA (1840).

${ }^{6}$ Aesop - “The Frogs Asking for a King”, In: Aesop’s Fables, Simon \& Brown, Hollywood, FL (560 BC), pp. 94.

${ }^{7}$ H. Morton - “Fountains of Rome”, Macmillan Co., New York, NY (1966).

${ }^{8}$ G. Bachelard - “The Poetics of Space: The Classic Look at How We Experience Intimate Places”, Beacon Press, Boston, MA (1958), pp. xxxiii.

${ }^{9}$ Life without Buildings - “Any Other City”, Tugboat, UK (2001).

10 J. Mulvey - "Review of Life without Buildings’ Any Other City”, NME (February 23, 2001), retrieved from http://www.nme.com/reviews/4076.

${ }^{11}$ B. Watterson - “Attack of the Deranged Mutant Killer Monster Snow Goons”, Andrews and McMeel, Kansas City, MO (1992), pp. 53.

12 The Thrills - “You Can't Fool Old Friends with Limousines”, In: Let’s Bottle Bohemia, Virgin, UK (2004).

${ }^{13}$ L. McNeil, G. McCain - "Please Kill Me: The Uncensored Oral History of Punk”, Grove Press, New York, NY (2006), pp. 243.

14 The Sex Pistols - “EMI”, In: Never Mind the Bullocks... Here’s the Sex Pistols, Virgin, UK (1977).

15 The Clash - “Complete Control”, In: The Clash, CBS, UK (1977).

${ }^{16}$ The Beatles - “A Day in the Life”, In: Sgt. Pepper’s Lonely Hearts Club Band, Parlophone, UK (1967).

${ }^{17}$ D. MacLeod - "Kids of the Black Hole: Punk Rock in Postsuburban California”, University of Oklahoma Press, Norman, OK (2010), pp. 44. 
${ }^{18}$ N. Rombes - “A Cultural Dictionary of Punk: 1974 - 1982”, Continuum, New York, NY (2009), pp. 7.

${ }^{19}$ G. Stein - “Rose Does Something”, In: The World is Round, Shambhala, Boston, MA (1938).

${ }^{20}$ M. Paterson - "The Monks and Me: How 40 Days at Thich Nhat Hanh’s French Monastery Guided Me Home”, Hampton Roads, Charlottesville, VA (2012), pp. 28.

${ }^{21}$ A. Frost, R. Yarrow - “Improvisation in Drama”, Palgrave Macmillan, New York, NY (2007), pp. 220 - 221.

${ }^{22}$ H. Caen - "Patter of a Tiny Mind”, San Francisco Examiner \& Chronicle/Sunday Punch (January 9, 1977).

${ }^{23}$ J. Rumi - “Signs of the Unseen”, Shambhala, Boston, MA (1994), pp. 129.

${ }^{24}$ Iggy Pop - “Turn Blue”, In: Lust for Life, RCA, New York, NY (1977).

${ }^{25}$ A. Kamenetz - "How Web-Savvy Edupunks Are Transforming American Higher Education”, Fast Company 138 (September 1, 2009), retrieved from http://www.fastcompany.com/magazine/138/who-needsharvard.html?page $=0 \% 2 \mathrm{C} 0$.

${ }^{26}$ B. de Ligt - “The Conquest of Violence: An Essay on War and Revolution”, Routledge, London, UK (1937).

${ }^{27}$ C. Stanislavski - “Building a Character”, Routledge, New York, NY (1936), pp. 39.

${ }^{28}$ K. Gibran - "The Prophet”, Paideia, Belgrade, Serbia (1923).

${ }^{29}$ J. Kerouac - “On the Road”, Penguin, New York, NY (1957), pp. 4-5. 